\title{
Privatisation and Workers' Compensation in Privatised State-Owned Enterprises in Bangladesh
}

\author{
Mehadi Mamun (Corresponding author) \\ Edith Cowan University, Sydney campus, Australia \\ E-mail:m.mamun@ecu.edu.au
}

Mamun Billah

Western Sydney university, Bankstown campus, Australia

E-mail: m.billah@westernsydney.edu.au

Received: November 9, 2020 Accepted: December 9, 2020 Published: December 15, 2020

doi: 10.5296/bms.v12i1.18070 URL: https://doi.org/10.5296/bms.v12i1.18070

\begin{abstract}
This paper examines the impact of privatisation on workers' compensation in privatised state-owned enterprises in Bangladesh. The study employs five case studies using a qualitative approach. Studying multiple cases is considered more reliable as it permits replication and extension. The qualitative approach helps to build a holistic picture, which allows for the assembling of a comprehensive and complete report of the issues under investigation. The research finds that workers' compensations in most privatised case study organisations are less than their counterparts in comparable state-owned and privately-owned organisations. The findings have important implications for the privatisation programmes in Bangladesh as the study focuses on workers who are the major workforce of privatised organisations and generates qualitative data that provides greater insight into the impact of privatisation on workers' compensation in Bangladesh.
\end{abstract}

Keywords: Conditional aid, Privatisation, Workers, Bangladesh

\section{Introduction}

The focus of institutional aid agencies' assistance efforts in Bangladesh has been on the promotion of macro and micro economic reforms designed to develop private sector and improve the efficiency and profitability of the private sector. For example, major institutional 
aid agencies such as the International Monetary Fund (IMF) and the World Bank have focused on economic development through the implementation of larger macro-economic reforms under various Structural Adjustment Programmes (SAPs), which have required the Bangladeshi government to implement a range of prescribed policies and reforms, including the privatisation of state-owned enterprises (Uddin \& Hopper, 2003; Boubakri et al., 2008; World Bank, 2011). It is assumed that these donor-driven interventions will lead to private sector-led economic growth, which will in turn decrease levels of poverty and, more broadly, improve socio-economic conditions in Bangladesh. In this way, conditional aid has become an important element of the development paradigm and a significant amount of official development assistance (ODA) has been provided in Bangladesh on the condition that the Bangladeshi government privatises its state-owned enterprises. For example, the World Bank provided US\$ 388.39 million to Bangladesh from 2004 to 2010 on the condition that the Bangladeshi government restructured and privatised its state-owned enterprises (World Bank, 2011). The view of these agencies is closely aligned to core tenets of development theory tied to neo-classical economic theory that argue ownership transfers from state to market will enhance management controls and improve performance and productivity (Vicers \& Yarrow, 1988; Boubakri et al., 2004).

This paper argues that privatisation and measures to increase profitability of privatised organisations are blunt instruments without taking into account workers' conditions in privatised organisations. To explicate this argument, this article focuses on the impact of privatisation schemes on workers' compensation in recently privatised organisations in Bangladesh. A deeper understanding of the impact of privatisation on workers' compensations can provide useful insights, and also contribute to the broader debate on the role of privatisation in Bangladesh.

\section{Aid Conditionality and Privatisation in Bangladesh: A Literature Review}

In Bangladesh, foreign aid has been the most important source of outside finance since its independence in 1971. According to the Ministry of Finance of Bangladesh (2003, 2012), from 1971 to 2011 some US\$54.5 billion in foreign aid was provided to Bangladesh. Other statistics highlight this dependency. For example, Bangladesh received about US $\$ 1.8$ billion in foreign aid in the 2008/2009 financial year, which equated to US\$12 per capita and $52.2 \%$ of the country's development budget (BBS, 2010). Hence, the Bangladesh governments' dependence on foreign aid has given the power to aid donors to impose a range of conditions (Uddin \& Hopper, 2003; Boubakri et al., 2008).

Conditions are usually imposed at project, sectoral, or macro and micro economic levels in Bangladesh. For project such as the World Bank's state-owned enterprise reform project, conditions involved the name of the industries to be reformed, the schedule of work, the way of executing the project, and the way and use of funding. For sectoral issues such as the power sector, conditions involved input pricing, sector management, decision making, and distribution system. For macro and micro economic issues, supply of money, inflation, trade pattern, deregulation, exchange rate, taxes and tariffs, and government's spending are some of 
the important considerations (Sobhan, 1991; world Bank, 2011).

The World Bank (2002) and Duncan et al. (2002) argue that conditionality is essential in Bangladesh because accountability and governance structures are not good enough. Hossain and Cheng (2002) argue that Bangladesh has begun to demonstrate substantial progress in using conditional aid to generate economic growth. They note that GDP growth, averaged $4.5 \%$ in the $1980 \mathrm{~s}$, but had improved to an average of $5.5 \%$ in 2002 . However, according to figures provided by the World Bank (2012), the poverty level in this nation was still above 30\%. Leandro and Schafer (1999) and Dijkstra (2002) argue that inappropriate conditions tied to the giving of foreign aid are a key barrier to the desired outcomes of aid in Bangladesh.

As observed by Haq and Abrar (1999), aid was received mainly in the form of food aid and commodity aid after the independence in 1971. In the late 1970s and first half of the 1980s aid came in with few conditions. In the later half of the $1980 \mathrm{~s}$, strict conditionality was imposed to promote structural reforms. The World Bank and IMF, for example, introduced Structural Adjustment Programmes (SAPs) in Bangladesh in 1986 through conditionality which required the Bangladesh government to implement a range of prescribed policies and reforms, including the privatisation of state-owned enterprises (SOEs) (Uddin \& Hopper, 2003; Boubakri et al., 2008). Privatisation refers to the purposeful sale of state-owned enterprises by a government to private proprietors. The World Bank and IMF include privatisation as a component of their Structural Adjustment Programmes (SAPs), which are based on specific interpretations of the value of economic liberalisation, competition, free trade, and little government interference (Cook, 1986).

Though Structural Adjustment Programmes (SAPs) were introduced in Bangladesh in 1986, the privatisation programme started back in the mid-1970s on the advice of aid donors (Sobhan, 1991; Uddin \& Hopper, 2003). After liberation, the first Bangladesh government adhered to pro-socialist ideology and nationalised a large number of industries (Ahmed, 2004). By 1974, the public sector controlled about 350 state-owned enterprises (SOEs) and was responsible for more than $92 \%$ of total fixed assets of the industrial sector (Uddin \& Hopper, 2003). The nationalisation policy, however, was not successful and profitable (Ahmed, 2004; Momen, 2007). After the political change in 1975, the new government declared a revised industrial policy, through which the public sector-led industrialisation strategy was abandoned and capitalist ideology was embraced (Momen, 2007). Institutional aid agencies had a major influence upon that new direction because the government was dependent on the aid agencies for assistance and the aid agencies took the opportunity to influence the government (Sobhan, 1991). For example, the World Bank had responsibility for reporting on the state of the country to the Donor Countries Consortium (DCC), and used the DCC's collective sanctions to enforce World Bank directives requiring the government to promote the private sector (Uddin \& Hopper, 2003).

In the 1980s, the Bangladesh government consistently committed to the capitalistic economic philosophy and followed aid donors' advice to privatise SOEs (Sobhan, 1991; Uddin \& 
Hopper, 2003). The World Bank and IMF created Structural Adjustment Programmes (SAPs) for the developing countries in the 1980s as a new financing mechanism and introduced in Bangladesh in 1986 which also required the Bangladesh government to privatise SOEs (Uddin \& Hopper, 2003; Boubakri et al. 2008).

After the 1980s, privatisation of SOEs was continued under all governments in Bangladesh as the aid agencies had a strong influence upon the privatisation policy (Sobhan, 2002; Privatisation Commission, 2010a). For Example, the IMF provided about US\$ 954.4 million to Bangladesh under the Poverty Reduction and Growth Facility (PRGF) arrangement between 1990 and 2007, and the principal condition of the PRGF arrangement comprised privatisation or closure of state-owned enterprises (SOEs) (IMF, 2011). The World Bank jointly with three other development partners, such as the Asian Development Bank, the United Kingdom's Department for International Development, and the Government of Japan, also prepares a Country Assistance Strategy (CAS) for Bangladesh. One of the strategic priorities of CASs $(2001,2006,2011)$ was an emphasis on a stable macroeconomic environment through following trade policy towards liberalisation and creating an enabling policy environment for private sector-led economic growth. In terms of creating an enabling environment for private sector-led economic growth, a policy agenda in CASs (2001, 2006, 2011) was the restructure and/or privatisation of SOEs.

Following aid donors' advice to privatise SOEs, a total of 372 SOEs were privatised by the Bangladesh government from 1975 to 1992. And, after the establishment of the Privatisation Board in 1993, a total of 39 SOEs were also privatised by the Bangladesh government's different ministry and the Privatisation Board (Uddin \& Hopper, 2001; Chowdhury, 2008; Privatisation Commission, 2010a, 2010b, 2016). The Privatisation Board was dissolved after the establishment of the Privatisation Commission in July 2000. The Bangladesh government formed the Privatisation Commission with the financial and administrative power to well run the privatisation programme through the enactment of the Privatisation Act 2000, and a total of 38 SOEs were privatised by the Privatisation Commission between its establishment and 2015 (Privatisation Commission, 2010b, 2016).

Inclusive study of the privatisation of state-owned enterprises (SOEs) in Bangladesh is relatively limited. Most research on privatisation in Bangladesh has been concerned with measuring its impact on performance and profitability. The World Bank (2016) argued that privatisation in Bangladesh would increase business efficiency and the government's fiscal position, hence promoting investment, economic growth, and reducing poverty. Boubakri et al. (2008) study also found that privatisation brought major improvements to efficiency, output, and profitability in the privatised businesses in Bangladesh. However, Sobhan (2002) found that privatised firms, with a few exceptions, did not significantly improve performance but contributed to enterprise closures and unemployment. Ahmed (2004) studied the post-privatisation performance of Bangladeshi firms and found that denationalised mills did not perform substantially better than public mills. In some cases, denationalised mills' production fell away faster than production at their public counterparts. The author 
summarised that there was no clear link between privatisation and improved financial performance. Similarly, Islam (2015) saw the spectre of privatisation programmes that led many enterprises to the edge of collapse after privatisation.

As the above discussion shows that there are mixed perspectives in the literature about the effectiveness of privatisation in Bangladesh. There are also mixed perspectives in the literature about privatisation programmes' experiences in other developing countries. Djankov and Murrell (2000) conducted a meta-analysis of 31 empirical studies and concluded that private enterprises in developing countries were more productive than state-owned enterprises. Another study examining the performance of 121 former state-owned enterprises in Vietnam showed that there were major improvements in efficiency, profitability and employee income (Loc et al. 2006). However, Stiglitz (2003) criticised IMF's SAPs in which rapid privatisation was applied in developing countries, and argued that the subsequent readjustments led to a deteriorating economic situation, increased poverty and social unrest. Killick's (2004) study also showed that of the 100 World Bank adjustment programmes, only 25 percent were successful. The dominant interpretation of effectiveness, hence, has almost always emphasised financial performance and profitability, usually by comparing pre- and post-privatisation data. Attention has not been given to the impact of privatisation on workers. Therefore, there is scope to improve our understanding of the impact of privatisation on workers more directly through examining the impact on the compensations for workers in privatised firms in Bangladesh.

\section{Methodology}

The study uses semi-structured face-to-face interviews with factory floor workers and management level employees, and document analysis for multiple data collection from the five privatised case study organisations, five state-owned and five privately-owned organisations that belong to the same industries and size. An indirectly structured interview allows themes to emerge, as participants construct their own meanings from situations through the conversation (McMurray et al., 2004). Multiple sources of data enhance the validity, reliability and credibility of research (Parry, 1998).

The research project is an exploratory study, employing a case study research method. Exploratory study is seen by Neuman (1997) as a study which is conducted into a problem or issue where there are few or no previous studies to refer to. In Bangladesh, the available literature and existing knowledge about the impact of privatisation on workers' compensations is very limited and offer no clues for a conceptual framework or notable propositions. The case study research method is the preferred research method because the focus is on a contemporary phenomenon in a real-life context. Yin (2003, p. 13) defines case study as 'an empirical inquiry that investigates a contemporary phenomenon within its real-life context, and in which multiple sources of evidence are used'.

The study employs five case studies using a qualitative approach. The development of similar results over multiple cases, can inform more robust findings (Yin, 2003; Noor, 2008), and a 
qualitative approach helps to explore new topics by getting into the settings where people carry out their lives (Denzin \& Lincoln, 2005). Hence, a qualitative approach is appropriate for the purpose of this study as it explores employees' perspectives and privatisation's impact on their lives.

\section{Case Selection and Data Collection}

According to the Privatisation Commission of Bangladesh (2010b, 2016), a total of 38 state-owned enterprises were privatised by the Privatisation Commission from its establishment in 2000 to 2015 . Of the 38 privatised organisations, 14 were fully operational, three had changed businesses, one was partly operational, and 20 were closed.

This study focused on the 14 organisations which were privatised by the Privatisation Commission from seven government corporations and fully operational after privatisation. The following table 1 presents the name of the seven government corporations and their controlled SOEs which were privatised by the Privatisation Commission and fully operational after privatisation.

Table 1. Corporations' controlled total SOEs which were privatised and fully operational

\begin{tabular}{|l|c|}
\hline Name of the corporations & Fully operational privatised SOEs \\
\hline Bangladesh Jute Mills Corporation & 1 organisation \\
\hline Bangladesh Sugar and Food Industries Corporation & 3 organisations \\
\hline Bangladesh Textile Mills Corporation & 2 organisations \\
\hline Bangladesh Chemical Industries Corporation & 4 organisations \\
\hline Bangladesh Fisheries Development Corporation & 1 organisation \\
\hline Bangladesh Steel and Engineering Corporation & 2 organisations \\
\hline $\begin{array}{l}\text { Bangladesh Forest Industries Development } \\
\text { Corporation } \quad 1 \text { organisation }\end{array}$ \\
\hline
\end{tabular}

Source: Privatisation Commission of Bangladesh (2010b, 2016)

Of the seven corporations, five case study organisations have come from the five corporations. The five case study organisations (jute mill, sugar mill, textile mill, paper mill and fishing net factory) are of varying size, span different industries and are based in different geographical districts of Bangladesh. This variety offers greatest scope for comparing the impact of privatisation on workers across different industries and size.

Workers' compensations at the five privatised case studies are compared with the workers' compensations at five state-owned organisations and five private organisations that are belonged to the same industries and size as case studies to know the impacts of privatisation on workers' compensations in privatised state-owned organisations, and to explore 
relationships in the data between relative levels of compensations and industry, size and type of ownership.

In total 125 interviews were conducted across the five privatised organisations ( 25 interviews from each organisation), and the same number interviews were conducted in five SOEs as well as in five private organisations. Research participants from each organisation were selected through proportional stratified random sampling from a list of staff to avoid bias and sampling errors. Employees of an organisation were first divided into six stratums such as male permanent workers, female permanent workers, male casual workers, female casual workers, male management level employees, and female management level employees because no other information was available about the employees in the staff list. After dividing employees into six stratums, proportional stratified random sampling was conducted to obtain potential interviewees name from six stratums.

Staff list from each organisation was collected after obtaining written consent from the authority to participate in this study. External independent gatekeepers were also used in this study to access the interviewees, and local NGOs were the go between the researchers and the factory employees as gatekeepers. Gatekeepers, by virtue of their personal or work relationship to an interviewee, are able to access the interviewees (Keesling, 2008). These gatekeepers were independent of the workplaces and they insured that owners or other workers never knew the participants' identity. Since, it was important to conceal the identity of the interviewees from owners to protect them from any repercussions of participating in this study, all interviews were conducted outside of the workplace and after office hours, wherever interviewees felt secure and could freely talk.

In order to provide maximum protection of their anonymity, no identifiable information (e.g. name, address) of the interviewees was collected during the interview. For the same reason, oral rather than written consent was sought. An information letter (in Bengali) was offered to each interviewee, and where their literacy was insufficient to understand the content, a detailed verbal explanation was given. The interviews were conducted by the researchers and an audio recording was made with a digital recorder with the participants' permission. The interviews were conducted in Bengali and the translations done by the researchers, who are native Bengali speakers and live in Australia. It should also be mentioned that the researchers' Bengali background assisted them in recognising, understanding and interpreting some of the more subtle points from the interviews.

\section{Cross-Case Analysis and Major Research Findings}

As mentioned earlier, the study has used semi-structured face-to-face interviews with factory floor workers and management level employees, and document analysis of relevant secondary source materials. Document analysis requires that data be examined and interpreted in order to elicit meaning, gain understanding, and develop knowledge of a phenomenon (Rapley, 2007). The analytic procedure entails finding, selecting, appraising (making sense of), and synthesising data contained in documents (Labuschagne, 2003; 
Bowen, 2009). The relevant World Bank and IMF policy papers and reports about Bangladesh, and the Bangladesh government's policy papers have been analysed to understand the policy and processes of privatisation in the country. The five privatised, five state-owned and five private organisations' documents relating to wages, benefits, and other relevant documents have been analysed to know how the workers' interests have been preserved.

All semi-structured interviews were recorded and then transcribed and then translated from Bengali into English. The audio recorded interviews were transcribed and translated as true and as faithful to the participant's words as possible. They captured sufficient detail of what the participants conveyed in their interviews. All transcribed data of this research have been read several times and categorised into relevant major elements of compensation. Compensation refers to the combination of money and other benefits that an employee receives for doing his/her job (Cambridge English Dictionary, 2017), and major elements of compensation are remuneration, increments, and extra benefits (Walton, 1975; Zohir, 2007).

According to Yin (2003) cross-case analysis is a technique that is particularly useful in the analysis of multiple case studies, and such an analysis is generally easier to follow and more robust. Hence, cross-case analysis of this study brings together the five case studies, it compares and analyses the findings, and creates a platform for writing conclusions.

After analysing the documents and interviews, it was found that in three privatised organisations (the sugar mill, textile mill and fishing net factory), permanent workers' minimum wages were less than those at comparable state-owned and private businesses. In one case (the jute mill), minimum wages were aligned to the minimum monthly wage rate at other jute factories (state-owned and private). And, in another case (the paper mill), permanent workers received a higher minimum wage than their counterparts at comparable state-owned and private factories.

In most cases, floor workers reported that their wages were not enough to support their families, and a large number of the floor workers said that they relied on financial assistance from other family members to buy basic necessities. One of the workers said: I have to look after my parents, a young sister and three members of my own family. I cannot support them adequately with my one income. My father cannot work; I feel so much stresses'. Another floor worker said: 'With my income I cannot support my family, somehow I manage. I have to pay rent. My kids are going to school. I have to borrow money very frequently. I feel very stressed to maintain my family and feel lots of worry to think about my retirement days'.

In four privatised organisations, casual workers were worse off than casuals working in similar state-owned and private factories. And, in one case (the paper mill), casual workers' daily wages were same as their counterparts at the private organisation, but less than those paid by the state-owned. Casual workers miserable living conditions are revealed in the following comments by one casual: 'I live from hand to mouth. I have to look after my parents and four members of my own family. So, it is very very tough to support my family 
with my one income. I have to borrow money for schooling my children and looking after my family'.

Of the five privatised organisations, only one (the textile mill) did not give its permanent workers a yearly pay increase. Two businesses, the jute mill and fishing net factory, gave permanent workers an annual pay increase, but it didn't match increases at the comparable state-owned and private factories. At the privatised sugar mill, annual pay increases matched those of another private sugar mill, but were less than the increases at the comparable state-owned sugar mill. The privatised paper mill paid its permanent workers greater yearly pay increases than those offered at the comparable state-owned and private paper mills.

Permanent workers had access to a provident fund (a retirement savings programme) in three case study organisations. However, those three organisations' contributions to the provident funds were less than the state-owned organisations' contributions and same as the private organisations' contributions. In two cases (the textile mill and fishing net factory), workers had no access to a retirement savings programme. Permanent workers employed by state-owned businesses received allowances for healthcare, accommodation, transport and tiffin. This did not happen at the five privatised case study organisations.

Three privatised organisations, like state-owned organisations, paid permanent workers two religious festival bonuses each year, each being equivalent to one month's basic wage. One privatised organisation (the textile mill) did not pay a festival bonus, while the fishing net factory paid a reduced bonus. In three cases, permanent workers' attendance bonuses were same as their counterparts at the state-owned and private organisations. In two cases (the textile mill and fishing net factory), workers received no attendance bonuses.

\section{Conclusions and Implications}

The main purpose of this study has been to examine the impact of privatisation on workers' compensation in privatised state-owned enterprises in Bangladesh. The research finds that workers' compensation in most privatised case study organisations are less than their counterparts in comparable state-owned and privately-owned organisations. The study also finds that industry type and organisational size of the privatised organisations have not affected workers' compensation. Though the findings of this study are applicable to the related organisations and employees, common findings and patterns from the case study organisations' interviews and documents suggest that the findings of this study can be applied and generalised across other privatised organisations' workers compensation. Hence, this paper argues that there is a need to place greater emphasis on a more context sensitive approach to privatisation programmes in Bangladesh.

The outcomes of this research will help international donors, Bangladesh's policymakers, privatised organisations, and workers in various ways. The international institutional donors attach conditions to their aid in Bangladesh, requiring privatisation of SOEs; they argue that their prescribed policies will help to increase private investments, improve socio-economic conditions and the welfare of citizens. However, this study finds that most of the privatised 
organisations are closed down after privatisation and privatisation of SOEs has not improved workers' compensation in most of the running privatised organisations. International institutional donors, therefore, can gain a better understanding of the challenges of privatisation programmes from this study and should review their 'one-size-fits-all' approach before suggesting any policies, such as extensive privatisation of SOEs.

This research finds that there is much room for the Bangladesh Government and the Privatisation Commission's thinking about their privatisation programme. Bangladeshi policymakers should be highly cautious when selecting state-owned enterprises for privatisation. The Privatisation Commission should be given authority through law or a condition of privatisation to monitor privatised organisations' activities and ensure that every privatised organisation strictly follows Bangladesh Labour Law. The research findings also identify some areas where privatised organisations should pay their attentions. For example, the government's set minimum wages, a retirement savings plan, regular increments, festival bonuses, medical allowances, house-rent allowances, and transport allowances should be provided to improve workers' job satisfaction.

To date, most research on privatisation in Bangladesh has examined the connections between privatisation and profitability. Little scholarly attention has been paid to how privatisation affects workers. The findings of this study show that international institutional donors, Bangladeshi policymakers, and the owners of privatised organisations should revise their strategies and pay greater attention to its affects on compensation for workers. As with most research, this study cannot stand alone and further research is suggested. Another study can be conducted to find out the reasons of closure of more than half of the privatised organisations after privatisation. An avenue of further research can also be to compare the findings of this study with the experiences of workers in privatised firms in other developing countries. Given that privatisation has become a key instrument of international institutional aid donors, and its consequences affect millions across the developing world, the need to unveil the human face of privatisation policies has never been more prescient. To ignore the breadth of the impact of privatisation, including its impact on workers, is to ignore the broader role of privatisation and the extent to which it can deliver true and broad-based improvements to the lives of workers in the developing countries.

\section{References}

Ahmed, M. U. (2004). Privatization in Bangladesh. Geneva: International Labour Organization.

Bangladesh Bureau of Statistics. (2010). Statistical Year Book of Bangladesh - 2010. Government of Bangladesh, Dhaka, Bangladesh.

Boubakri, N., Cosset, J. C., \& Guedhami, O. (2004). Privatization, corporate governance and economic environment: Firm-level evidence from Asia. Pacific-Basin Finance Journal, 12(1), 65-90. https://doi.org/10.1016/S0927-538X(03)00016-7 
Boubakri, N., Cosset, J. C., \& Guedhami, O. (2008). Privatisation in Developing Countries: Performance and Ownership Effects. Development Policy Review, 26(3), 275-308. https://doi.org/10.1111/j.1467-7679.2008.00411.x

Bowen, G. A. (2009). Document Analysis as a Qualitative Research Method. Qualitative Research Journal, 9(2), 27-40. https://doi.org/10.3316/QRJ0902027

Chowdhury, M. A. S. (2008). An Overview on Privatization Program. Privatization Commission, Bangladesh.

Cook, P. (1986). Liberalisation in the Context of Industrial Development in Less Developed Countries. Manchester Discussion Papers in Development Studies, no. 8602, University of Manchester.

Denzin, N. K., \& Lincoln, Y. S. (Ed.) (2005). The Handbook of Qualitative Research. California: Sage Publications.

Dijkstra, A. G. (2002). The Effectiveness of Policy Conditionality: Eight Country Experiences. Development and Change, 33(2), 307-335. https://doi.org/10.1111/1467-7660.00256

Djankov, S., \& Murrell, P. (2000). The Determinants of Enterprise Restructuring in Transition: An Assessment of the Evidence. World Bank Publications. https://doi.org/10.1596/0-8213-4815-9

Duncan, A., Sharif, I., Landell-Mills, P., Hulme, D., \& Roy, J. (2002). Bangladesh: supporting the drivers of pro-poor change. Report of DFID, London.

Haq, M. S., \& Abrar, C. R. (1999). Aid, Development and Diplomacy - Need for an Aid Policy. Dhaka: The University Press Limited, Bangladesh.

Hossain, S., \& Cheng, M. Y. (2002). Bangladesh: building for a better future? International Journal of Social Economics, 29(10), 813-821. https://doi.org/10.1108/03068290210444449

International Monetary Fund. (2011). Bangladesh: Staff Report for the 2011 Article IV Consultation. Washington DC: International Monetary Fund. https://doi.org/10.5089/9781463923907.002

Islam, M. R. (2015). Privatising government owned enterprises. The Daily Star. Available at https://www.thedailystar.net/supplements/24th-anniversary-the-daily-star-part-1/privatising-g overnment-owned-enterprises-73282

Keesling, R. (2008). Gatekeeper. In P.J. Lavrakas (Ed.), Encyclopedia of survey research methods (pp. 300-301). California: Sage Publications.

Killick, T. (2004). Politics, Evidence and the new aid agenda. Development Policy Review, 22(1), 5-29. https://doi.org/10.1111/j.1467-8659.2004.00235.x

Labuschagne, A. (2003). Qualitative Research - Airy Fairy or Fundamental? The Qualitative Report, 8(1). Retrieved from http://www.nova.edu/ssss/QR/QR8-1/labuschagne.html 
Leandro, J. E., \& Schafer, H. (1999). Towards A More Effective Conditionality: An Operational Framework. World Development, 27(2), 285-300. https://doi.org/10.1016/S0305-750X(98)00127-2

Loc, T. D., Lanjouw, G. E. R., \& Lensink, R. (2006). The Impact of Privatization on Firm Performance in a Transition Economy: The case of Vietnam. Economics of Transition, 14(2), 349-389. https://doi.org/10.1111/j.1468-0351.2006.00251.x

McMurray, A. J., Pace, R. W., \& Scott, D. (2004). Research: a commonsense approach. Southbank Victoria: Thomson.

Ministry of Finance. (2003). Bangladesh Economic Review 2003. Finance Division, Ministry of Finance, Government of Bangladesh.

Ministry of Finance. (2012). Bangladesh Economic Review 2012. Finance Division, Ministry of Finance, Government of Bangladesh.

Momen, M. N. (2007). Implementation of Privatization Policy: Lessons from Bangladesh. The Innovation Journal: The Public Sector Innovation Journal, 12(2), Article 4.

Neuman, W. L. (1997). Social Research Methods: Qualitative and Quantitative Approaches. London: Allyn and Bacon.

Noor, K. B. M. (2008). Case Study: A Strategic Research Methodology. American Journal of Applied Sciences, 11(5), 1602-1604. https://doi.org/10.3844/ajassp.2008.1602.1604

Parry, K. W. (1998). Grounded theory and social process: A new direction for leadership research. Leadership Quarterly, 85-105. https://doi.org/10.1016/S1048-9843(98)90043-1

Privatisation Commission. (2010a). Privatization in Bangladesh Opportunities and Potentials. Privatization Commission, Bangladesh.

Privatisation Commission. (2010b). Study Report of Privatized SOEs. Privatization Commission, Bangladesh.

Privatisation Commission. (2016). Achievement in the Privatization. Privatization Commission, Bangladesh.

Rapley, T. (2007). Doing conversation, discourse and document analysis. California: Sage Publications. https://doi.org/10.4135/9781849208901

Sobhan, R. (2002). Privatisation in Bangladesh: An Agenda in Search of a Policy. Centre for Policy Dialogue, Dhaka, Bangladesh.

Sobhan, R., \& Mahmud, S. A. (1991). The economic performance of denationalized industries in Bangladesh: The case of the jute and cotton textile industries. BIDS Research Report New Series 129, Dhaka, Bangladesh.

Stiglitz, J. E. (2003). Globalization and Its Discontents, New York: WW Norton \& Company. 
Uddin, S., \& Hopper, T. (2001). A Bangladeshi Soap Opera: Privatisation, Accounting, and Regimes of Control in a Less Developed Country. Accounting Organizations and Society, 26(7/8), 643-672. https://doi.org/10.1016/S0361-3682(01)00019-8

Uddin, S., \& Hopper, T. (2003). Accounting for Privatisation in Bangladesh: Testing World Bank Claims. Critical Perspectives on Accounting, 14, 739-774. https://doi.org/10.1016/S1045-2354(02)00188-0

Vickers, J., \& Yarrow, G. (1988). Privatisation in Britain. In W. Paul, \& W.T. MacAvoy (Eds.), Privatisation and State-Owned Enterprises: Lessons from the United States, Great Britain and Canada (pp. 209-246). London: Kluwer Academic Publishers. https://doi.org/10.1007/978-94-011-7429-9_5

Walton, R. E. (1975). Criteria for Quality of Working Life. In L. E. Davis, \& A. B. Cherns (Eds.). The quality of working life. New York: The Free Press.

World Bank. (2001). Bangladesh Country Assistance Strategy 2001. Washington DC: World Bank.

World Bank. (2002). Bangladesh government and development partners emphasise good governance and quicker reforms. Press Release No: 2002/242/SAR, Washington DC: World Bank.

World Bank. (2006). Bangladesh Country Assistance Strategy 2006. Washington DC: World Bank.

World Bank. (2010). Bangladesh Country Assistance Strategy 2011. Washington DC: World Bank.

World Bank. (2011). Bangladesh - Enterprise Growth and Bank Modernization Project. Washington DC: World Bank.

World Bank. (2012). World Bank data sets. Washington DC: World Bank.

World Bank. (2016). Bangladesh - Country Partnership Framework 2016. Washington DC: World Bank.

Yin, R. K. (2003). Case Study Research: Design and Methods. California: Sage Publications.

Zohir, S. C. (2007). Role of Dhaka Export Processing Zone: Employment and Empowerment. Research Report. Dhaka: Bangladesh Institute of Development Studies.

\section{Copyright}

Copyright for this article is retained by the author(s), with first publication rights granted to the journal.

This is an open-access article distributed under the terms and conditions of the Creative Commons Attribution license (http://creativecommons.org/licenses/by/4.0/). 